\title{
EFFECT OF Artemisia absinthium ESSENTIAL OIL ON ANTIOXIDATIVE SYSTEMS OF BROILER'S LIVER
}

\author{
Ljiljana M. Kostadinović*, Ivana S. Čabarkapa, Jovanka D. Lević, Šandor M. Kormanjoš, \\ Sanja J. Teodosin, Slavica A. Sredanović
}

University of Novi Sad, Institute of Food Technology in Novi Sad, Bulevar cara Lazara 1, 21000 Novi Sad, Serbia

\author{
*Corresponding author: \\ Phone: +381695275855 \\ E-mail: ljiljana.kostadinovic@fins.uns.ac.rs
}

\begin{abstract}
The effect of Artemisia absinthium essential oil (AAEO) on enzymatic activity of superoxide-dismutase $(S O D)$, glutathione-peroxidase $(G S H P x)$, glutathione-reductase $(G R)$, peroxidase $(P O D)$, xantine-oxidase $(X O D)$ and non-enzymatic (content of lipid peroxides $(L P X)$ and gluthathione $(G S H)$ ) antioxidative status of broilers infected with mixture of oocysts of Eimeria tenella, Eimeria mitis and Eimeria necatrix in comparison to coccidiostat salinomycin was investigated. The in vivo investigation were carried out on 120 Arbor acres broilers of both sexes. Broilers were randomly distributed into four groups. Group A was uninfected and untreated; group B was infected and was kept untreated; group C preventively received coccidiostatic salinomycin in quantity of $60 \mathrm{mg} / \mathrm{kg}$ of feed and was inoculated with coccidia species at $21^{\text {st }}$ day-of-age and group $\mathrm{D}$ received in feed $A A E O$ in quantity of $3 \mathrm{~g} / \mathrm{kg}$ and was infected with Eimeria oocysts at $21^{\text {st }}$ day-of-age. Livers were collected for the subsequent evaluation of antioxidative status. It was concluded that $A A E O$ added in feed for broilers prevented the development of coccidia oocysts and therefore it can be used as prophylactic feed additive.
\end{abstract}

Key words: Artemisia absinthium, antioxidative system, coccidiosis, salinomycin, prophylactic feed additive

\section{INTRODUCTION}

Coccidiosis is an infective disease of the digestive tract which is the most frequent with poultry, causing a decrease in daily increment, prolonge fattening, poorer skin pigmentation, slower feed conversion and increase mortality. Coccidiosis is traditionally treated by chemotherapy, but the persistent appearance of drug - resistant strains of coccidia indicate the importance of developing alternative strategies (Braunius, 1982).

Many anticoccidian drugs have been developed and introduced in the poultry industry all over the world. One of them is polyether monocarboxylic acid - salinomycin. The use of salinomycin is also possible in other animals (cattle, pigs) as a growth stimulant and for improving feed utilization (Visek, 1978).

The increasing resistance of avian coccidia (protozoa) to anticoccidial drugs currently used by the poultry industry has stimulated the search for new methods of control (Allen et al., 1997). Many authors investigated alternatives to antibiotics (Langhout, 2000; Mellor, 2000; Ocak et al., 2008).

Essential oils have recently been reported as alternative to antibiotics in animal production and are claimed to be "digestive enhancers" (Williams and Losa, 2001). They are very complex mixtures of compounds, such as tannins, terpenoids, alkaloids and flavonoids. Many in vitro studies 
(Demirel et al., 2011; Lević et al., 2011) reported antimicrobial properties of essential oils. In addition to their antimicrobial activity, essential oils possess various biological activities such as antioxidant activity (Aliyu et al., 2012; Radivojević et al., 2012) and stimulate the digestion process (Langhout, 2000). Introduction of essential oils in animal feed may have promising potential as a growth and health promoters without adverse effects.

The genus Artemisia belongs to the family Compositae (Asteraceae) with over 300 species spread worldwide. The essential oil obtained from wild plant Artemisia absinthium shows antibacterial, antifeedant, antipyretic, fertility increasing, cytostatic and antimalarial activities (Khattak et al., 1985).

Considering above mentioned characterristics of Artemisia absinthium essential oil objective of this study was to compare prophylactic efficacy of the conventional coccidiostat (salinomycin) and Artemisia absinthium essential oil on artificially induced broiler coccidiosis. The comparative assessment was based on the clinical symptoms and changes in catalytic activity of important protective enzymes in liver homogenates of healthy and artificially infected broilers.

\section{MATERIALS AND METHODS}

\section{Chickens and Housing}

The experimental protocol was approved by the local Ethics Committee and the principles of animal protection were strictly followed. Experiments under in vivo conditions were performed on 120 broilers of both sexes of the heavy Arbor acres line. One day old broilers were raised in a clean and disinfected room under standard conditions. Broilers were fed using standard basal diet with the access to water and food ad libitum. Faecal samples were taken daily in order to monitor the possibility of infection. Temperature and lighting regimens were in accordance with the recommendation of the breeder. The initial room temperature of $32-33^{\circ} \mathrm{C}$ was reduced weekly by $1^{\circ} \mathrm{C}$ to a final temperature of $28^{\circ} \mathrm{C}$. The chickens were randomly divided into non-infected and infected groups. The se- cond group of broilers were infected with mixture of sporulated oocysts of $E$. tenella (5000 oocysts), E. mitis (5000 oocysts), and E. necatrix genus (10000 oocysts) collected from infected chicken farms. Coccidial oocysts of E. tenella, E. mitis and $E$. necatrix were obtained from the guts of infected chickens and they were preserved in $2.5 \%$ potassium dichromate solution to induce sporulation and subsequently kept in a refrigerator at $2-5{ }^{\circ} \mathrm{C}$ until use. The challenge infection of 21-day-old chickens was performed by oral administration of 1 $\mathrm{cm}^{3}$ oocyst suspension.

Artemisia absinthium essential oil was obtained from the Institute for Medicinal Plant Research "Dr Josif Pancic", Belgrade, Serbia.

\section{Experimental protocol}

Experiments under in vivo conditions were performed on broilers of the heavy line Arbor acres, of both sexes. One-day-old broilers, randomly selected, were divided into four groups, each containing 30 individuals.

Group A contained uninfected and unmedicated broilers (negative control group). Decapitation of 10 chickens was carried out at $30^{\text {th }}$ day-of-age.

Group $B$ contained infected and unmedicated broilers (positive control group). Inoculation of 21-day-old broilers was performed by p.o. application of $1 \mathrm{~cm}^{3}$ of coccidial suspension mixture of sporulated oocysts. Nine days later (at $30^{\text {th }}$ day-ofage), when first clinical signs of disease appeared (chickens were bristling, showed decreased food conversion, white mucous, later bloody diarrhea appeared, appetite decreased etc.), decapitation of 10 chickens was carried out.

Group $C$ contained broilers which preventively received coccidiostat salinomycin in quantity of $60 \mathrm{mg} / \mathrm{kg}$ of feed (Group $\mathrm{C}_{1}$ ) and the remaining broilers were inoculated with laboratory derived coccidia species at $21^{\text {st }}$ day-of-age (Group $\mathrm{C}_{2}$ ). Decapitation of 10 chickens were carried out at $30^{\text {th }}$ dayof-age. Group $D$ contained broilers which received $A A E O$ in quantity of $3 \mathrm{~g} / \mathrm{kg}$ (Group $D_{1}$ ) and the remaining broilers were infected with Eimeria oocysts at $21^{\text {st }}$ 
day-of-age (Group $D_{2}$ ). Livers were collected at $30^{\text {th }}$ day-of-age.

The essential oil was given to the chickens three times a day.

The oocyst output was measured daily in each group, during the period from $6^{\text {th }}$ to $9^{\text {th }}$ day after the infection. A clean polyethylene sheet placed daily under each cage was used for the collection of excreta for oocyst analysis. Total faecal samples collected over each $24 \mathrm{~h}$ from each group, were placed in separate airtight plastic bags, homogenised thoroughly with a domestic mixer, and kept refrigerated until assessed for total oocyst counts. Homogenised samples were ten-fold diluted with tap water to be further diluted with saturated $\mathrm{NaCl}$ solution at a ratio of 1:10. Oocyst counts were determined using McMaster chambers and presented as the number of oocysts per bird (Hodgson, 1970).

The means of oocysts per bird (OPB) of faeces in treated groups were compared with $O P B$ values for non-treated control groups in order to evaluate the effects of the plant essential oil on avian coccidiosis induced by Eimeria spp. Bloody diarrhoea was investigated from $4^{\text {th }}$ to $6^{\text {th }}$ day after the challenge.

Bloody diarrheal score was described using numerical values from $0(-)$ to 3 $(+++)$. Zero corresponded to normal status, whereas 1, 2 and 3 corresponded to $33 \%, 33-66 \%$ and $66-99 \%$ of blood in total faeces, respectively.

Protein content was determined by the method of Prakash et al. (2010). In homogenized liver glutathione content, products of lipid peroxidation and the activities of antioxidant enzymes (SOD, GR, GSHPx, $P O D$ and $X O D$ ) were determined.

\section{Preparation of liver homogenate}

One gram of the liver was cut with scissors and homogenized in a mixer using 3 volumes of isotonic buffer $\left(0.05 \mathrm{~mol} / \mathrm{dm}^{3}\right.$ tris$\mathrm{HCl}, 0.25 \mathrm{~mol} / \mathrm{dm}^{3}$ sucrose, $\left.\mathrm{pH}=7.5\right)$. The homogenate was filtered through gauze into ice-cold tubes for further analysis (Chiu et al., 1976).

\section{Sample preparation for glutathione (GSH) determination}

Proteins from freshly prepared liver homogenates were separated by adding half the volume of $10 \%$ sulfosalicylic acid and centrifugated at $5000 \mathrm{rpm}$, for $5 \mathrm{~min}$, at $4{ }^{\circ} \mathrm{C}$. The supernatant was stored at $4{ }^{\circ} \mathrm{C}$, without freezing, and $\mathrm{GSH}$ determined within 24 hours. The GSH content in the liver homogenate was determined from the amount of sulfhydryl residues by means of Ellmann's reagent (Kapetanovic and Mieyal, 1979).

\section{Determination of enzymatic activity}

Superoxide-dismutase (SOD) (EC1.15.1.1) activity was determined by the spectrophotometric method based on the inhibition of adrenaline reduction to adrenochrome at $\mathrm{pH}=10.2$ (Kostadinović et al., 2001).

The glutathione-peroxidase (GSHPx) (EC 1.11.1.9) activity was determined by spectrophotometric measurement of absorbance at $412 \mathrm{~nm}$ with cumenhydroperoxide as the substrate (Chiu et al., 1976).

Activity of the glutathione-reductase $(G R)$ (EC 1.6.4.2.) was determined from the rate of $N A D P H$ oxidation and it was monitored by measuring the absorbance at $340 \mathrm{~nm}$ (Lukaszewicz-Hussain and Moniuszko-Jakoniuk, 2004).

Lipid peroxides $(L P x)$ was determined by thiobarbituric acid (TBA - test). The oxidation of cellular membrane lipids was measured via reaction of lipid peroxides with thiobarbituric acid (Simmon et al., 1974).

The determination of peroxidase (POD) (EC 1.11.1.7) activity was based on the catalytic oxidation of guaiacol by hydrogen peroxide as an electron acceptor (Kostadinović et al., 2011). The reaction of xanthine oxidation to uric acid was used for determination of xanthine-oxidase $(X O D)$ (EC 1.17.3.2) activity.

Spectrophotometric measurement was performed in $0.1 \mathrm{mmol} / \mathrm{dm}^{3}$ phosphate buffer, $\mathrm{pH}=7.5$, at $295 \mathrm{~nm}$ (Kostadinović et al., 2011).

\section{Statistical analysis}

The results given in tables are reported as the mean \pm standard deviations $(S D)$ of a 
number $(n)$ of independent determinations. The one way ANOVA analysis was performed to assess data differences between various groups using Statistica software version 10 (StatSoft inc. 2011). The data means were considered different at $P<0.05$.

\section{RESULTS AND DISCUSSION}

\section{Anticoccidial activity of $A A E O$ and salinomycin}

Bloody diarrhoea was observed from the fourth to sixth day after the infection with Eimeria spp. in all experimental groups except the uninfected control group. The intensity of bloody diarrhoea was lower in $\mathrm{C}_{2}$ group (treated with salinomycin) in comparison to other infected groups (Table 1).

Excreted oocysts count in the groups $\mathrm{C}_{2}$ and $D_{2}$ were lower in comparison to infected control group (B) (Table 2). Administration of $A A E O$ and coccidiostat salinomycin before infection with Eimeria spp. was shown to be associated with the reduction of oocyst output. The summary of statistical values obtained from 30 chickens in each test groups is shown in Table 2.

Table 1.

Intensity of bloody diarrhoea of chickens challenged with Eimeria spp. and treated with profilactic dose of salinomycin and $A A E O$

Experimental groups

$\mathrm{B}$
$\mathrm{C}_{2}$
$\mathrm{D}_{2}$
$\mathrm{~A}$

AAEO - Artemisia absinthium essential oil; A-negative control; B-positive control; $\mathrm{C}_{2}$ - salinomycin $60 \mathrm{mg} / \mathrm{kg}$ of feed and infected; $D_{2}-A A E O 3 \mathrm{~g} / \mathrm{kg}$ of feed and infected;

$0(-)$ - normal status; (+) - 33\%, (++) - 33-66\%, (+++)- $66-99 \%$ of blood in total faeces

Table 2.

Effectivenes of salinomycin and $A A E O$ on faecal oocyst counts and mortality rate in different treatment groups of broilers

\begin{tabular}{|c|c|c|c|c|c|}
\hline \multirow{3}{*}{ Group } & \multicolumn{4}{|c|}{ Oocysts excretion $\left(\times 10^{6}\right) /$ bird } & \multirow{3}{*}{$\begin{array}{l}\text { Mortality } \\
\text { rate (\%) }\end{array}$} \\
\hline & \multirow{2}{*}{$\begin{array}{r}\text { Day of infection } \\
21^{\text {st }} \text { day }\end{array}$} & \multicolumn{3}{|c|}{ After infection } & \\
\hline & & $24^{\text {th }}$ day & $27^{\text {th }}$ day & $30^{\text {th }}$ day & \\
\hline A & 0 & 0 & 0 & 0 & 3 \\
\hline $\mathrm{B}$ & $2.3 \pm 0.3^{b}$ & $34.5 \pm 1.8^{\mathrm{a}}$ & $3.8 \pm 0.4^{\mathrm{a}}$ & $0.4 \pm 0.1^{a}$ & 12 \\
\hline $\mathrm{C}_{2}$ & $1.0 \pm 0.1^{\mathrm{a}}$ & $2.2 \pm 0.2^{\mathrm{b}}$ & $0.1 \pm 0.02^{b}$ & $0^{\mathrm{b}}$ & 5 \\
\hline$D_{2}$ & $1.7 \pm 0.2^{b}$ & $7.3 \pm 0.1^{c}$ & $0.4 \pm 0.01^{\mathrm{c}}$ & $0.08 \pm 0.01^{\mathrm{c}}$ & 7 \\
\hline
\end{tabular}

Results are presented as mean \pm standard deviation $(n=3)$;

${ }^{\mathrm{a}-\mathrm{c}}$ Means within a column with different superscript differ significantly at $\mathrm{P}<0.05$;

AAEO - Artemisia absinthium essential oil; A - negative control; B-positive control; $\mathrm{C}_{2}$ - salinomycin $60 \mathrm{mg} / \mathrm{kg}$ of feed and infected; $D_{2}-A A E O 3 \mathrm{~g} / \mathrm{kg}$ of feed and infected
However, the non-treated chickens infected with Eimeria spp. showed significant excretion of oocysts in faeces (Table 2). The salinomycin treated broilers $\left(\mathrm{C}_{2}\right)$ showed complete reduction of oocyst in faeces at $30^{\text {th }}$ day. In $A A E O$ treatment group $\left(D_{2}\right)$ the oocysts output and mortality rate were lower in comparison to positive control group (B).Therefore it can be concluded that $A A E O$ was effective in reducing the oocyst output of the preventively treated and infected broilers.

Some herbal extracts have already been shown to possess a coccidiostat activity (Youn and Noh, 2001). Extracts and essential oils from aromatic plants are of interest for coccidiosis since several studies have shown substantial antimicrobial and antioxidative activity (Aliyu et al., 2012).

This biological activity has been mainly attributed to phenolic components. In vivo and in vitro tests have shown (Williams \& Losa, 2001) that phenols can be specifically used as oocysticides against Eimeria spp. (days after infection)

\begin{tabular}{llclll}
\hline 3 & 4 & 5 & 6 & 7 \\
\hline- & + & +++ & + & - \\
- & + & + & - & - \\
- & + & ++ & - & - \\
- & - & - & - & - \\
\hline
\end{tabular}


Table 3.

GSH and $L P x$ contents and activity of GSHPx, SOD, GR and XOD in liver homogenates

\begin{tabular}{c|ccccccc}
\hline Group & $\begin{array}{c}\text { GSH } \\
\text { (nmol/mg } \\
\text { protein) }\end{array}$ & $\begin{array}{c}\text { LPX } \\
\text { (nmol/mg } \\
\text { protein) }\end{array}$ & $\begin{array}{c}\text { GSHPX } \\
\text { (nmol/mg } \\
\text { protein } \\
\text { min) }\end{array}$ & $\begin{array}{c}\text { POD } \\
\text { (nmol/mg } \\
\text { protein } \\
\text { min) }\end{array}$ & $\begin{array}{c}\text { SOD } \\
\text { (nmol/mg } \\
\text { protein } \\
\text { min) }\end{array}$ & $\begin{array}{c}\text { GR } \\
\text { (nmol/mg } \\
\text { protein min) }\end{array}$ & $\begin{array}{c}\text { XOD } \\
\text { (nmol/mg } \\
\text { protein min) }\end{array}$ \\
\hline $\mathrm{A}$ & $0.6 \pm 0.08^{\mathrm{a}}$ & $0.4 \pm 0.05^{\mathrm{b}}$ & $4.8 \pm 0.6^{\mathrm{b}}$ & $5.7 \pm 1.5^{\mathrm{b}}$ & $10.8 \pm 2.8^{\mathrm{b}}$ & $31.7 \pm 3.1^{\mathrm{a}}$ & $20.4 \pm 3.8^{\mathrm{a}}$ \\
$\mathrm{B}$ & $1.3 \pm 0.2^{\mathrm{b}}$ & $3.5 \pm 0.2^{\mathrm{c}}$ & $7.6 \pm 1.6^{\mathrm{a}}$ & $2.8 \pm 0.9^{\mathrm{a}}$ & $5.8 \pm 0.9^{\mathrm{a}}$ & $21.5 \pm 1.2^{\mathrm{b}}$ & $18.6 \pm 2.0^{\mathrm{a}}$ \\
$\mathrm{C}_{1}$ & $0.9 \pm 0.06^{\mathrm{c}}$ & $0.3 \pm 0.08^{\mathrm{b}}$ & $7.9 \pm 1.3^{\mathrm{a}}$ & $8.5 \pm 2.0^{\mathrm{c}}$ & $15.2 \pm 2.8^{\mathrm{b}}$ & $52.7 \pm 2.5^{\mathrm{c}}$ & $46.6 \pm 7.6^{\mathrm{b}}$ \\
$\mathrm{C}_{2}$ & $1.4 \pm 0.1^{\mathrm{b}}$ & $0.2 \pm 0.08^{\mathrm{a}}$ & $12.2 \pm 3.2^{\mathrm{c}}$ & $1.8 \pm 0.3^{\mathrm{a}}$ & $2.8 \pm 0.2^{\mathrm{c}}$ & $11.3 \pm 1.4^{\mathrm{d}}$ & $22.8 \pm 2.7^{\mathrm{a}}$ \\
$\mathrm{D}_{1}$ & $0.9 \pm 0.03^{\mathrm{c}}$ & $0.3 \pm 0.02^{\mathrm{a}}$ & $4.4 \pm 0.3^{\mathrm{b}}$ & $6.7 \pm 0.9^{\mathrm{b}}$ & $15.0 \pm 3.6^{\mathrm{b}}$ & $34.6 \pm 2.1^{\mathrm{a}}$ & $29.2 \pm 1.4^{\mathrm{c}}$ \\
$\mathrm{D}_{2}$ & $1.3 \pm 0.1^{\mathrm{b}}$ & $0.2 \pm 0.01^{\mathrm{a}}$ & $11.0 \pm 1.2^{\mathrm{c}}$ & $1.3 \pm 0.2^{\mathrm{a}}$ & $5.7 \pm 0.2^{\mathrm{a}}$ & $18.0 \pm 2.6^{\mathrm{b}}$ & $21.6 \pm 3.4^{\mathrm{a}}$ \\
\hline
\end{tabular}

Results are given as mean \pm standard deviation $(n=3)$;

${ }^{a-d}$ Means within a column with different superscript differ significantly at $P<0.05$;

AAEO - Artemisia absinthium essential oil; A-negative control; B-positive control; $\mathrm{C}_{1}-60 \mathrm{mg}$ salinomycin $/ \mathrm{kg}$ of feed; $\mathrm{C}_{2^{-}} 60 \mathrm{mg}$ salinomycin $/ \mathrm{kg}$ of feed and infected; $\mathrm{D}_{1-}$ - AAEO $3 \mathrm{~g} / \mathrm{kg}$ of feed; $\mathrm{D}_{2^{-}}$AAEO 3g/kg of feed and infected

Phenols interact with the cytoplasmic membrane by changing its permeability for cations, like $\mathrm{H}^{+}$and $\mathrm{K}^{+}$. The dissipation of ion gradients leads to the impairment of essential processes in the cell, allows leakage of cellular constituents, resulting in water unbalance, collapse of the membrane potential and inhibition of ATP synthesis, and finally cell death (Ultee et al., 1999).

\section{Enzymatic activity in liver homogenates}

The content of $G S H$ and $L P x$ and the catalytic activity of selected enzymes of the antioxidative defense system determined in the liver homogenates of the control and experimental groups are shown in Table 3.

The content of GSH and activity of GSHPX in liver homogenates of broilers in group $B$ showed a significant increase $(P<0.05)$ in comparison with the group $A$, while the $P O D, S O D, X O D$ and $G R$ activity decreased (Table 3).

Glutathione (GSH) and glutathione peroxidase (GSHPX) are among the major antioxidant defences. GSH plays an important role in reduction the acute toxicity of xenobiotics and products of lipid peroxidation as a substrate for GSHPx.The reduction in GSH is in line with the report of Kumar et al. (2010) that exposure to coccidiosis caused a depletion of GSH levels in poultry broilers. Reduction in GSH level is an indication that detoxification is going on. GSHPx are ubiquitous multifunctional enzymes which play a key role in cellular detoxification. Concomitantly with the in- creased risk of lipid peroxidation in liver, there is an increase in the enzymatic activity of GSHPx. In line with literature data (Shanker et al., 2011) reduction of catalytic activity of superoxide-dismutase is expected.

The preventive doses of coccidiostat Salinomycin caused a significant $(P<0.05)$ increase of GSH content and catalase-activity of all investigated enzymes. Addition of salinomycin in feed increases GSHPX activity and reduces the need for high levels of GSH content, which took part in the detoxification of harmful compounds in the body. A significant increase of catalase-activity of $P O D$ compared to the corresponding control group was noticed, which was expected since $P O D$ catalyzes the oxidation of various proton donors with hydrogen peroxide. Salinomycin is ionophore coccidiostat and does act as a proton donor.

Infection with Eimeria spp. in group of broilers $\mathrm{C}_{2}$ nine days later $\left(30^{\text {th }}\right.$ day-ofage) resulted in significant increase of GSH content and higher activity of GSHPx, but content of $L P x$ and activity of $P O D, S O D, G R$ and $X O D$ were significantly decreased compared to the group $B$ and $\mathrm{C}_{1}$ group of broilers.

On the basis of the observed changes of enzymes activity, we may conclude that induction and inhibition of their activity in liver homogenates of broilers preventively treated with salinomycin and infected broilers continued until reaching the basic activity-level characteristic for the corres- 
ponding control group, i.e. having the tendency of eliminating the negative effects induced by the disease (Table 3 ).

In liver homogenates of preventively $A A E O$ treated broilers and then infected (group $D_{2}$ ) was observed a significant increase of $G S H$ content, decrease of $L P X$ content, induction of GSHPx activity and inhibition of $P O D$, SOD, GR and XOD activity in comparison with the control group A. This finding is in line with data published by Olanlokun (2008). Observed changes show positive preventive effects of applied $A A E O$. Its application leads to decreased number of coccidian and therefore reduced intensity of the disease induced by free-radical processes.

\section{CONCLUSIONS}

The results of this study indicate that $A A E O$ is an effective agent in reducing the oocyst output of the preventively treated and infected broilers and could be a potential source of protection against coccidiosis. Excreted oocysts in the groups treated with $3 \mathrm{~g} / \mathrm{kg} A A E O$ were lower than in the infected control group, but higher than in the salinomycin group.

Pathological changes in liver homogenates of artificially infected broilers intensified free radical processes. The obtained results show that infection with Eimeria oocysts exhibit negative effects on the antioxidant defense system in the liver of broilers and that $A A E O$ demonstrates protective role against Eimeria infection.

\section{ACKNOWLEDGMENTS}

The paper is a part of the research work on the project III-46012 and project TR31031 financed by the Ministry of Education, Science and Technological Development of the Republic of Serbia.

\section{REFERENCES}

1. Aliyu, A.B., Ibrahim, M.A., Ibrahim, H., Musa, A.M., Lawal, A.Y., Oshanimi, J.A., Usman, M., Abdul Kadir, I.E., Oyewale, A.O., Amupitan, J.O. (2012). Free radical scavenging and total antioxidant capacity of methanol extract of Ethulia conyoides groving in Nigeria. Romanian Biotechnological Letters, 17 (4), 7458-7465.
2. Allen, P.C., Lydon, J., Danforth, H.D. (1997). Effects of components of Artemisia annua on coccidia infections in chickens. Poultry Science, 76 (8), 1156-1163.

3. Braunius, B.W.W. (1982). Coccidiosis in Broilers: the Effective use of Anticoccidial drugs. World's Poultry Science Journal, 38 (3), 176185.

4. Chiu, D.T.Y., Stults, F.H., Tappel, A.L. (1976). Purification and properties of rat lung soluble glutathione peroxidase. Biochimica et Biophysica Acta, 445, 558-566.

5. Demirel, Z., Yilmaz-Koz, F.F., Karabay-Yavasoglu, N.U., Ozdemir, G., Sukatar, A. (2011). Antimicrobial and antioxidant activities of solvent extracts and the essential oil composition of Laurencia obtusa and Laurencia obtusa var. Pyramidata. Romanian Biotechnological Letters, 16 (1), 5927-5936.

6. Hodgson, J.N. (1970). Coccidiosis: oocystcounting technique for coccidiostat evaluation. Experimental Parasitology, 28, 99-102.

7. Kapetanovic, I.M., \& Mieyal, I.I. (1979). Inhibition of acetaminophen-induced hepatotoxicaly by phenacetin and its alkoxy analogs. Journal of Pharmacology and Experimental Therapeutics, 209, 29-30.

8. Khattak, S.G., Galani, S.N., Ikram, M. (1985). Antipyretic studies on some indigenous Pakistani medicinal plants. Journal of Ethnopharmacology, 14 (1), 45-51.

9. Kostadinović, Lj., Pavlovski, Z., Pavkov, S. (2001). Effect of amprolium on the lipid peroxidation and the activity of superoxide dismutase in broilers blood and liver. Archiv fur Geflugelkunde, 65 (3), 118-122.

10. Kostadinović, Lj., Pavkov, S., Lević, J., GaIonja-Coghill, T., Dozet, G., Bojat, N. (2011). Effect of sulphachloropyrazine on antioxidative systems in blood and liver of broilers. Acta Veterinaria Brno, 80, 165-170.

11. Kumar, M. R., Reddy, G. A., Anjaneyulu, Y., Reddy, G. D. (2010). Oxidative stress induced by Lead and Antioxidant potential of certain Adaptogens in poultry. Toxicol International, 17 (2), 45-48.

12. Langhout, P. (2000) New additives for broiler chickens. World's Poultry Science Journal, 16 (3), 22-27.

13. Lević, J., Čabarkapa, I., Todorović, G., Pavkov, S., Coghill-Galonja, T., Kostadinović, Lj. (2011). In vitro evaluation of antibacterial activity of essential oils from family Lamiaceae. Romanian Biotechnological Letters, 16 (2), 6034-6041.

14. Lukaszewicz-Hussain, A. \& Moniuszko-Jakoniuk, J. (2004). Liver catalase, glutathione peroxidase and reductase activity, reduced glutathione and hydrogen peroxide levels in acute intoxication with chlorfenvinphos, an organophosphate insecticide. Polish Journal of Environmental Studies, 13 (3), 303-309.

15. Mellor, S. (2000). Antibiotics are not the only growth promoters. World's Poultry Science Journal, 16 (1), 14-15. 
16. Ocak, N., Erener, G., Burak Ak, F., Sungu, M., Ozmen, A. (2008). Performance of broilers fed diets supplemented with dry peppermint (Mentha piperita L.) or thyme (Thymus vulgaris L.) leaves as growth promoter source. Czech Journal of Animal Science, 53 (4), 169-175.

17. Olanlokun, J.O. (2008). Protective influence of vitamin $\mathrm{E}$ on the antioxidant defense system in the whole blood and liver of normal and alloxan-induced diabetic rats. Indian Journal of Clinical Biochemistry and Nutrition, 23, 62-66.

18. Prakash, B.D., Manjunath, S., Kadi, S., Chetana, K., Vanishree, J. (2010). Oxidative stress and enzymatic antioxidant status in rheumatoid arthritis: a case control study. European Review for Medical Pharmacological Sciences, 14 (11), 959-967.

19. Radivojević. I.D., Stanković, M.S., Stefanović, D.D., Topuzović, M.D., Čomić, J. (2012). Antioxidative and antimicrobial properties of different extracts from Sideritis montana L. Romanian Biotechnological Letters, 17 (2), 71607168.

20. Shanker, K.S., Umesh, D., Meena, K., Priyambada, K. (2011). Ameliorative Activity of Withania somnifera Root Extract on Paraquat-indu- ced Oxidative Stress in Mice. Journal of Pharmacolology and Toxicology, 6, 433-439.

21. Simmon, L.M., Fatrai, Z., Jonas, D.E., Matkovics, B. (1974). Study of metabolism enzymes during the development of Phascoulus vulgaris. Biochem Physiol Pflanz, 166, 389-393.

22. STATISTICA (Data Analysis Software System) (2011). v.10.0. Stat-Soft, Inc, USA (www. statsoft.com).

23. Ultee, A., Kets, E.P. W., Smid, E.J. (1999). Mechanisms of action of carvacrol on the food borne pathogen Bacillus cereus. Applied and Environmental Microbiology, 65, 4606-4610.

24. Visek, W.J. (1978). The mode of growth promotion by antibiotics. Journal of Animal Science, 46, 1447-1469.

25. Williams, P., \& Losa, R. (2001). The use of essential oils and their compounds in poultry nutrition. World's Poultry Science Journal, 17, 14-15.

26. Youn, H. J. \& Noh, J. W. (2001). Screening of the anticoccidial effects of herb extracts against Eimeria tenella. Veterinary Parasitology, 96, 257-263.

\title{
УТИЦАЈ ЕТАРСКОГ УЉА БЕЛОГ ПЕЛЕНА НА АКТИВНОСТ ЕНЗИМА АНТИОКСИДАТИВНЕ ЗАШТИТЕ У ЈЕТРИ БРОЈЛЕРСКИХ ПИЛИЋА
}

\author{
Љиљана М. Костадиновић", Ивана С. Чабаркапа, Јованка Д. Левић, Шандор М. Кормањош, \\ Сања Ј. Теодосин, Славица А. Средановић
Универзитет у Новом Саду, Научни институт за прехрамбене технологије у Новом Саду, Булевар цара Лазара 1, 21000 Нови Сад

Сажетак: У раду је испитан утицај етарског уља белог пелена (Artemisia absinthium) $(A A E O)$ на ензимску активност супероксид дисмутазе $(S O D)$, глутатион пероксидазе (GSHPX), глутатион редуктазе $(G R)$, каталазе $(C A T)$, пероксидазе $(P O D)$ и ксантин-оксидазе $(X O D)$, као и садржај липидних пероксида $(L P x)$ и глутатиона $(G S H)$ у хомогенатима јетре бројлера инфицираних смесом ооциста Eimeria tenella, Eimeria mitis и Eimeria necatrix у односу на кокцидиостатик салиномицин. In vivo испитивање је спроведено на 120 бројлера (Arbor acres), оба пола. Бројлери су подељени у четири групе: Група А је неинфицирана и нетретирана (негативна контрола); група Б је инфрицирана и нетретирана (позитивна контрола); група Ц је превентивно добијала кокцидиостатик салиномицин у количини од 60 мг/кг хране и инокулирана кокцидиама 21. дана старости. Група Д је у храни добијала AAEO у количини 3 г/кг хране и 21. дана старости инфицирана смесом ооцисти Eimeria spp. За оцену антиоксидативног статуса бројлерских пилића извршено је узорковање јетре. Утврђено је да етарско уље белог пелена додато у храну за бројлере у количини од 3 г/кг хране, утиче на смањење слободнорадикалских процеса, изазваних инфекцијом кокцидијама, тако што утиче на активирање неензимског и ензимског система заштите. На основу добијених резултата, закључено је да етарско уље Artemisia absinthium, које је додато у храну за бројлере у количини од 3 г/кг хране, спречава развој кокцидија, има позитиван утицај на активирање антиоксидативног система заштите јетре бројлера и стога се може користити у профилакси кокцидиозе.

Кључне речи: Artemisia absinthium, антиоксидативни систем, кокцидиоза, салиномицин, профилактички додатак храни за животиње 